\title{
Teaching Efficacy of Elementary Students Teachers
}

\author{
Maria Nancy Quinco-Cadosales, PhD \\ La Salle University, Ozamiz, Philippines \\ nancymari71@gmail.com
}

\begin{abstract}
The curriculum of Bachelor in Elementary Education requires prospective teachers to undergo student teaching. In the student teaching phase, the student teacher is mentored by a student teaching supervisor and cooperating teachers. They are exposed to both on and off-campus training. In the on and off-campus training, the student teachers performed at least 15 teachings, 1 straight teaching, and a final demonstration. All of these teachings are evaluated by the cooperating teachers. The student teaching supervisor joined the cooperating teachers during the straight teaching and final demonstration to evaluate the teaching performance of the student teachers. Individual consultations were conducted to provide feedback on how to improve the teaching skills of the student teachers. In the final demonstration in the off-campus is observed by the Education Program Specialists of the Department of Education. The Education Program Specialists and the School Principal conducted a conference with the student teachers in the presence of the Student Teaching Supervisor and Dean of the College of Teacher Education. In the conference, feedbacking on the strengths and weaknesses of the student teachers' teaching performance was done. It is a way of the University to receive feedback from the Education Program Specialists which could be input on how to enhance the Student Teaching Program. The training of the student teachers in the private and public elementary schools may have bearing on the development of their teaching efficacy. Definition of the literature on the concept of teaching efficacy centers on one's belief of his/her competencies. With this premise, the researcher employed the constructivist model of qualitative research to describe the teaching efficacy of student teachers. A focused group discussion was conducted to describe the indicators of teaching efficacy. Statements describing teaching efficacy were organized in a questionnaire. To establish the reliability of the items, the questionnaire was pretested to 37 student teachers who were doing their observation and participation prior to student teaching/internship. The questionnaire yielded a Cronbach alpha of $91 \%$. The result signified that the items are reliable. The questionnaire was then administered to the 24 student teachers. Based on the data gathered, three core categories based on the weighted means of the items emerged. These core categories centered on training, professional, and personal competencies. It was further described that the student teachers' level of teaching efficacy is generally very high. In conclusion, the on and off-campus training of the student teachers contributed much to the development of their teaching efficacy. The training had developed their professional and personal competencies. For further usability of the questionnaire developed from this study, it is recommended that a broader scope be considered, other variables that correlate to teaching efficacy be identified, and pretest and posttest be considered to describe the significant difference after ample training is provided to the student teachers.

Key Words: teaching efficacy, elementary, student teachers
\end{abstract}

\section{Introduction}

Student teaching is the summative field experience of the prospective teachers in the teacher education curriculum. This is the transitional phase between the last year of preservice education and future role of full-time teacher (Bustos, Cruz, San Mateo \& Idos, 2001). In the student teaching phase, each student teacher is engaged in full-time teaching responsibilities under the guidance andsupervision of an experienced cooperating teacher and afull-time university student teaching supervisor.

The current issue and full text archive of this journal is available at http://jraspublications.org/index.php/JRAS/issue/archive

Journal of Research in Administrative Sciences (JRAS)

VI(I), 7-12, ISSN: 2664-2433
Student teaching is the apex of all the Experiential Learning Courses. It is the total immersion of the prospective teacher in the real life of becoming a teacher. During practice teaching, the prospective teacher also called as student teacher experiences the rudiments of teaching in a cyclical process of planning, actual teaching, and evaluating learning. The student teacher walks the whole process of teaching with a mentor, who is called the cooperating teacher. The student teacher puts into actual 
practice all that were learned in the content and theory courses, strategies or methods of teaching as well as put into test the pedagogical content knowledge acquired in related courses prior to Student Teaching. In this phase, it is necessary to master the competencies needed as clearly emphasized in the National Competency-Based Standards for Teachers (NCBTS) and CMO 30, s. 2004 and its regional adaptation (Teacher Education Council, 2009).

Cadosales (2004) mentioned that student teaching is an avenue for the student teachers to experience the real teaching-learning processes. During the student teaching phase, the student teachers undertake guided observation and participation that allow them to observe what is going on in a classroom in an organized way. The designed series of lessons throughout the semester allow the student teachers to learn by observing, participating, recording information and interacting with their cooperating teachers, both on-campus and off-campus, and student teaching supervisors.

The actual teaching exposure of the student teachers in the student teaching phase may help them appreciate the teaching profession and eventually developed their teaching skills. As one of the student teaching supervisors and a faculty of the College of Teacher Education, the researcher is interested to determine the teaching efficacy elementary student teachers.

\section{Framework of the Study}

Self-efficacy is one's beliefs about his/her personal competence or effectiveness in a given area (Hoy and Hoy, 2009). It refers to the beliefs in one's capabilities to organize and execute the courses of action required to produce given attainments (Bandura, 1997). Self-efficacy involves judgments of capabilities specific to a particular task. Pajares (1997) emphasized that self-efficacy is a context-specific assessment of competence to perform a specific task.

Teaching efficacy is a teacher's belief that s/he can reach even difficult students to help them learn. Self-efficacy theory predicts that teachers with a high sense of efficacy work harder and persist longer even when students are difficult to teach. These teachers are less likely to experience burnout (Fives, Hamman, and Olivarez, 2005). Teachers' sense of efficacy is higher in schools where the other teachers and administrators have high expectations for students and where teachers receive help from their principals in solving instructional and management problems (Hoy and Hoy 2009). They further concluded that any experience or training that helps teachers succeed in the task of teaching give them a foundation for developing a sense of efficacy. Teachers' efficacy is related to commitment to teaching (Coladarci, 1992) and job satisfaction (Caprara et al., 2003 in Hoy and Hoy, 2009).

Research on self-efficacy and achievement suggests that performance in school is improved and self-efficacy is increased when students adopt short-term goals to judge progress, use specific learning strategies, and receive rewards based on quality of performance (Graham and Weiner, 1996). Teaching efficacy appears to be one of the few personal characteristics of teachers that is correlated with students' achievement (Ashton and Webb in Quinco, 2000). Greater efficacy leads to greater effort and persistence which leads to better performance (Hoy and
Hoy, 2009).

Cashman (1999) studied the efficacy of the student teaching experiences involving careful screening process for the selection and placement of student teachers, opportunities for sharing and modeling, focused on-site training, and a degree of student teachers' autonomy provide a better understanding of the student teachers' role in student teaching.

In the cooperating teachers and student teachers relationship, the two are engaged in a mentoring process. Podsen \& Denmark (2000) defined mentoring as a sustained relationship between a novice and an expert. In a teacher-mentoring relationship, the expert provides help, support, and guidance that helps the novice develop the necessary skills to enter or continue his/her career path. In this particular study, the experts are referred to as the cooperating teachers and the student teaching supervisor while the novice is the student teacher. Moreover, Frank (2005) emphasized that mentoring program generally pair a student with a carefully matched mentor to engage in quality relationship for a period of time. In the mentoring program, the relationship helps the cooperating teachers and student teaching supervisor provide experiences to the student teachers to gain self-esteem, learn valuable social skills, and have increased academic aspirations and performance.

Given the learning opportunities provided by the cooperating teachers and student teaching supervisors, it the premise of the researcher that the student teachers develop certain qualities of teaching efficacy. The literature cited had encouraged the researcher to describe the teaching efficacy of the Bachelor of Elementary Education (BEED) student teachers.

\section{Objectives of the Study}

This present study aimed to identify and describe the teaching efficacy of elementary student teachers.

\section{Methodology}

This study employed the sequential method of research. Both the qualitative and quantitative methods were combined to describe the teaching efficacy of student teachers. Through structured focused group discussion, the qualities of teaching efficacy of student teachers were formulated. The constructivist design articulated by Charmaz (in Creswell, 2012) is the model of this present study as shown in Figure 1.

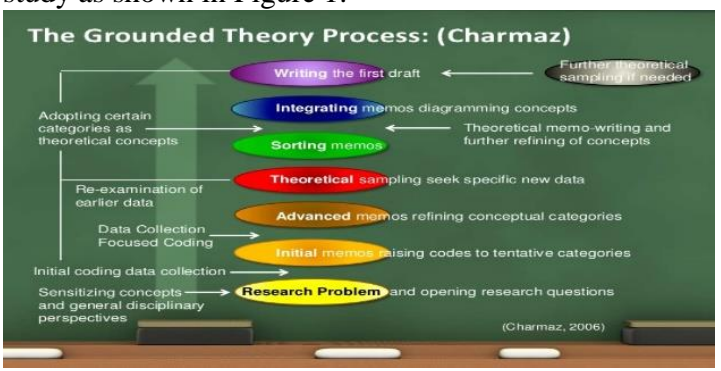

Figure 1. Constructivist design, Charmaz (2006)

In the constructivist design, the focus is on the meanings ascribed by the participants in a study. The views, values, beliefs, feelings, assumptions, and ideologies of individuals 
than in gathering facts and describing acts are given emphases in the constructivist model.

The elementary student teachers were the participants of the study. The researcher conducted focused group discussion to describe the qualities of the student teachers teaching efficacy. Based on the qualitative result of the FGD and readings done by the researcher, a questionnaire was constructed. It was subjected to a pretest and established the Cronbach's alpha which is a measure of internal consistency, that is, how closely related a set of items are as a group. After the statistical analysis, the items were $91 \%$ reliable.

There were 24 Bachelor in Elementary Education student teachers who participated in the study. These student teachers were enrolled in Student Teaching during the second semester of the Academic Year 2014-2015. To complete their teaching experiences, they were both exposed to on and off-campus teaching. The on-campus training was conducted in a non-sectarian basic education school. The off-campus training was conducted at in an elementary public school. The student teachers were exposed to on and off-campus student teaching to complete their experience teaching in private and public elementary schools.

The qualities for teaching efficacy were determined and subjected to a pretest to 37 student teachers who were enrolled in Observation and Participation. The researcher personally conducted the pretest. After the student observers answered the questionnaire, the researcher solicited their ideas if there are items or words that were difficult to understand. They proposed that item on "I experience less stress when teaching" will be modified by putting in a parenthesis the word fatigue to refer to stress. The final item was I experience less stress (fatigue) when teaching.

The student teachers' rating of the qualities of teaching efficacy used the scoring guide as follows:

$\begin{array}{lll}5 & - & 80 \% \text { to } 100 \% \text { True of me } \\ 4 & - & 60 \% \text { to } 79 \% \text { True of me } \\ 3 & - & 40 \% \text { to } 59 \% \text { True of me } \\ 2 & - & 20 \% \text { to } 39 \% \text { True of me } \\ 1 & - & 1 \% \text { to } 19 \% \text { True of me }\end{array}$

To describe the levels of the student teachers' teaching efficacy, the weighted means were interpreted as follows:

\begin{tabular}{|c|c|c|c|c|}
\hline \multirow{2}{*}{\multicolumn{5}{|c|}{$\begin{array}{c}4.21- \\
\text { High teaching efficacy }\end{array}$}} \\
\hline & & & & \\
\hline 3.41 & - & 4.20 & - & High \\
\hline \multicolumn{5}{|c|}{ teaching efficacy } \\
\hline 2.61 & - & 3.40 & - & \\
\hline \multicolumn{5}{|c|}{ Moderately High teaching efficacy } \\
\hline 1.81 & - & 2.60 & - & Slightly \\
\hline \multicolumn{5}{|c|}{ High teaching efficacy } \\
\hline 1.00 & . & 1.80 & - & Low \\
\hline
\end{tabular}
teaching efficacy weighted mean, frequency and percentage distribution to describe the teaching efficacy of elementary student teachers. The qualities of the teaching efficacy were described using the weighted mean. The levels of the student teachers' teaching efficacy were described using frequency and percentage contribution.

\section{Results and Discussion}

The order of the discussion in the results and discussion section were presented according the objective of this study. Table 1 presents the profile of the teaching efficacy as rated by the student teachers.

Table 1. Teaching Efficacy of Student Teachers

\begin{tabular}{|l|c|c|}
\hline \multicolumn{1}{|c|}{ Statements } & Mean & $\begin{array}{c}\text { Qualitative } \\
\text { Description }\end{array}$ \\
\hline I believe that I am capable to teach. & 4.88 & VHTE \\
\hline I am capable to organize the lesson I teach. & 4.83 & VHTE \\
\hline I execute the actual teaching with confidence. & 4.71 & VHTE \\
\hline I attain my objectives in teaching. & 4.79 & VHTE \\
\hline I observe sound judgments of my capabilities to do a specific task. & 4.67 & VHTE \\
\hline I perform the assigned teachings as scheduled. & 4.75 & VHTE \\
\hline I help difficult students to learn. & 4.71 & VHTE \\
\hline I find ways to make the difficult lessons easier to understand. & 4.83 & VHTE \\
\hline I work hard to prepare my teachings. & 4.92 & VHTE \\
\hline I am willing to spend extra hours to complete my teachings. & 4.92 & VHTE \\
\hline I experience less stress (fatigue) when teaching. & 4.08 & HTE \\
\hline I receive help from my co-student teachers in preparing my lessons. & 4.75 & VHTE \\
\hline $\begin{array}{l}\text { I am mentored to solve instructional problems by my } \\
\text { Cooperating Teachers }\end{array}$ Student Teaching Supervisor & 4.71 & VHTE \\
\cline { 2 - 3 }$>$ Cooperating Teachers & 4.83 & VHTE \\
\hline Student Teaching Supervisors & 4.79 & VHTE \\
\hline I am committed to teach. & 4.88 & VHTE \\
\hline I apply my learning strategies on how to do the actual teaching. & 4.92 & VHTE \\
\hline $\begin{array}{l}\text { I receive recognitions based on the quality of my teaching performance from } \\
\text { my }\end{array}$ & & \\
\cline { 2 - 3 } & 4.79 & VHTE \\
\hline
\end{tabular}




\begin{tabular}{|c|c|c|}
\hline I exert great efforts to succeed in my teachings. & 4.83 & VHTE \\
\hline \multicolumn{2}{|l|}{ I learn from the comments and modeling from my } & VHTE \\
\hline$>\quad$ Student Teaching Supervisors & 4.75 & VHTE \\
\hline \multicolumn{3}{|l|}{ I learn from my on-site training } \\
\hline$>$ On-campus & 4.88 & VHTE \\
\hline$>\quad$ Off-campus & 4.96 & VHTE \\
\hline I understand my roles as a student teacher. & 4.88 & VHTE \\
\hline I develop the necessary skills to continue the teaching profession. & 4.83 & VHTE \\
\hline \multicolumn{3}{|l|}{ I develop a quality relationship with my } \\
\hline$>\quad$ Co-student teachers & 4.79 & VHTE \\
\hline Cooperating Teachers & 4.88 & VHTE \\
\hline$>\quad$ Student Teaching Supervisors & 4.79 & VHTE \\
\hline I enhance my self-esteem in the entire student teaching experiences. & 4.79 & VHTE \\
\hline I feel contented after my teachings. & 4.79 & VHTE \\
\hline I extend extra time with the pupils who had difficulty in learning. & 4.75 & VHTE \\
\hline I reflect after each teaching to identify what to be improved more. & 4.83 & VHTE \\
\hline I am happy doing the teaching job. & 4.79 & VHTE \\
\hline I learn valuable social skills. & 4.88 & VHTE \\
\hline I am happy that I choose the teaching profession. & 4.79 & VHTE \\
\hline Grand Mean & 4.79 & VHTE \\
\hline
\end{tabular}

$\begin{array}{lll}\text { Legend: } & 4.21-5.00 & \text { - Very High } \\ \text { Teaching Efficacy } & \text { (VHTE) } & \\ & 3.41-4.20 & \text { - High Teaching } \\ \text { Efficacy } & \text { (HTE) } & \\ & 2.61-3.40 & \text { - Moderately High } \\ \text { Teaching Efficacy } & (\mathrm{MHTE}) & \\ & 1.81-2.60 & \text { - Slightly High } \\ \text { Teaching Efficacy } & (\mathrm{SHTE}) & \\ & 1.00-1.80 & \text { - Low Teaching } \\ \text { Efficacy } & \text { (LTE) } & \end{array}$

The data show that the qualities on teaching efficacy were rated very high. Only one quality is rated high by the student teacher. For the description of the qualities, the researcher will consider those with 4.80 to 5.00 weighted means.

Among the qualities of the teaching efficacy, the student teachers learned more from their off-campus training (4.96). This finding implies that the opportunities to teach in the Department of Education (DepEd) have helped the student teachers to hone their teaching skills. In the public schools, the student teachers rendered more actual teaching. The more they are exposed to actual teaching, the more they develop not only the skills to teach but the confidence to teach as well. As revealed by the student teachers during the focused group discussion, exposure to real/actual teaching helped them to understand the teaching profession. Further, the actual teaching contributed to the development of their self-confidence.

Secondly, it can be noticed that the student teachers work hard to prepare their teachings (4.92). The preparation to teaching is evident when the student teacher is preparing the lesson plans and instructional materials to be approved by the cooperating teacher. Once the lesson plan is approved, the student teacher will study not only the content of the lesson but on how to deliver it using multiple teaching aids. Every actual teaching is evaluated by the cooperating teacher. A post conference is conducted every after the evaluation of teaching. With this, the student teacher applies his/her learning strategies on how to do the actual teaching (4.92). The learning strategies employed by the student teacher are evident how they apply the suggestions given by the cooperating teachers and student teaching supervisor.

Thirdly, the next group of self-efficacy qualities rated very high (4.88) are on the student teachers' belief on their capability to teach; commitment to teach; understanding their roles as a student teacher; learning valuable skills; learning from their on-campus training; and development of a quality relationship with his/her cooperating teachers. The self-efficacy qualities described by the student teachers were more on the development of their personal qualities which support the claim of Coladarci (1992) that teachers' efficacy is related to commitment to teaching. Further, the student teachers mentioned that the teaching experiences developed their passion to teach, compassion to the learners, love of the teaching profession. Repeatedly, the student teachers mentioned that along the way of conducting the actual teaching, they learn to appreciate the teaching profession, understand the roles of a teacher, examine their character, become more innovative, and become more a motivated person.

Fourthly, the student teachers rated the following qualities of self-efficacy as very high (4.83) like being capable to organize the lesson they teach; finding ways to make the difficult lesson easier to understand; being mentored to solve instructional problems by his/her student teaching supervisor; exerting great efforts to succeed in his/her actual teachings; developing the necessary skills to continue the teaching profession; and reflecting after each teaching to identify what areas to be improved more. These qualities of teaching efficacy are centered on the teaching skills of the student teachers. The student teachers emphasized the value of the mentoring guide provided by the student teaching supervisor. In the student teaching 
phase, the student teaching supervisor plays a vital role in honing the teaching skills of the student teachers. They regularly met every day. The student teaching supervisor regularly monitors the teaching performance of the student teachers by observing actual teaching and conducting oneon-one conference. Common difficulties encountered by the student teachers are addressed in the inputs provided by the student teaching supervisor.

Noticeably, among the indicators of self-efficacy, experiencing less fatigue has the lowest weighted mean (4.08). Although this rating indicates that the student teachers have high self-efficacy but a slight degree of stress (fatigue) is experienced when teaching. The preparation of lesson plan and the conceptualization of the teaching materials require more time for the student teachers. When they do the straight teaching (teaching all learning areas), most of the student teachers are experiencing the difficulty to manage their time.

Figure 1 shows the emerged concepts on teaching efficacy.

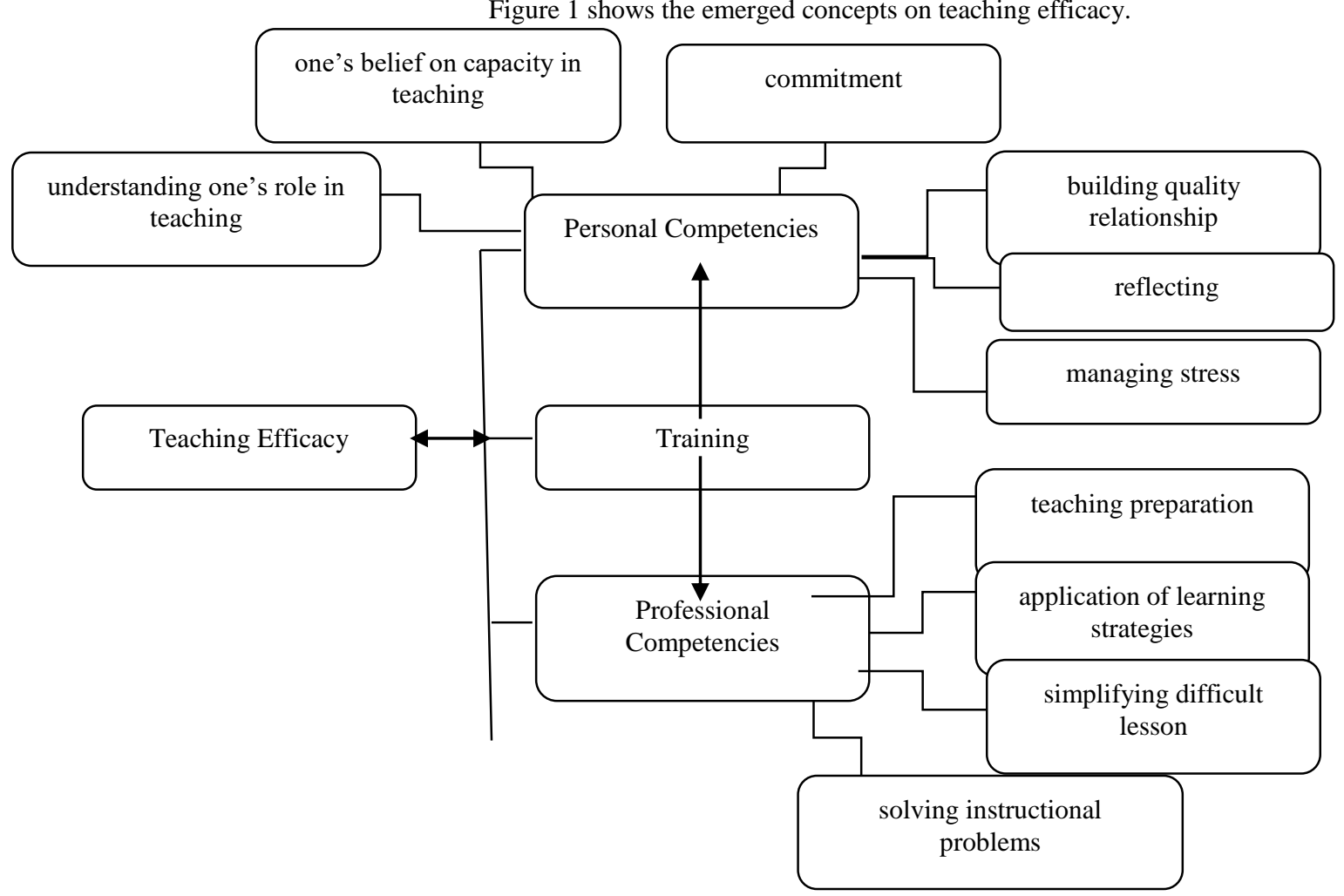

Figure 1. Emerging Framework on Teaching Efficacy

The responses of the student teachers as shown in the weighted means of the ratings reveal that teaching efficacy is centered on the following core categories: on and offtraining; professional competencies in terms of teaching preparation, application of learning strategies, ability to organize the lesson, finding ways to make difficult lessons easy, solving instructional problems, understanding one's role in teaching; and personal competencies in terms of one's belief on their capability to teach, commitment, building quality relationship, reflecting every after teaching, managing stress.

As shown in the schematic model, sufficient training of the student teachers led to the development of their competencies. The more time they are given to do actual teachings allow them to embrace the roles and responsibilities of a teacher. The guidance they receive develop their sense of ownership of what they are doing. This led to the development of their belief that they can do things because they believe on their capabilities and skills. The levels of the teaching efficacy of the student teachers are displayed in Table 2.

Table 2. Levels of Teaching-Efficacy of Student Teacher 


\begin{tabular}{|c|c|c|c|}
\hline $\begin{array}{c}\text { Mean } \\
\text { Range }\end{array}$ & $\begin{array}{c}\text { Qualitative } \\
\text { Description }\end{array}$ & frequency & Percent \\
\hline $\begin{array}{c}4.21- \\
5.00\end{array}$ & $\begin{array}{c}\text { Very High } \\
\text { Teaching Efficacy }\end{array}$ & 23 & 95.83 \\
\hline $\begin{array}{c}3.41- \\
4.20\end{array}$ & $\begin{array}{c}\text { High Teaching } \\
\text { Efficacy }\end{array}$ & 1 & 4.17 \\
\hline $\begin{array}{c}2.41- \\
3.40\end{array}$ & $\begin{array}{c}\text { Moderately High } \\
\text { Teaching Efficacy }\end{array}$ & - & - \\
\hline $\begin{array}{c}1.81- \\
2.60\end{array}$ & $\begin{array}{c}\text { Slightly High } \\
\text { Teaching Efficacy }\end{array}$ & - & - \\
\hline $\begin{array}{c}1.00- \\
1.80\end{array}$ & $\begin{array}{c}\text { Low Teaching } \\
\text { Efficacy }\end{array}$ & - & - \\
\hline \multicolumn{2}{|c|}{ TOTAL } & 24 & 100 \\
\hline
\end{tabular}

Almost all $(95.83 \%)$ of the student teachers have very high self-efficacy. This finding implies that the student teachers have developed the confidence on their ability to teach. Only one of them has high teaching efficacy with a weighted mean of 3.94. Generally, the student teachers had high beliefs on their professional and personal competencies. These competencies had influenced in the development of their teaching efficacy.

\section{Conclusion}

From the data gathered, it can be deduced that the teaching experiences of the student teachers had developed their teaching efficacy. In this particular study, three emerging concepts arose from the descriptions of the student teachers. The core categories include training, professional, and personal competencies.

\section{Recommendations}

For more usability of this present research, it is recommended that broader scope will be considered in future research endeavors; other variables will be identified to correlate to teaching efficacy; and the questionnaire on teaching efficacy will administered both in pretest and posttest to test the significant difference.

\section{References}

$i$. Bandura, A. (1997). Self-efficacy in cognitive development and functioning. Educational Psychologist, 28, 117-148.

ii. Bustos, A. S., A. A. Cruz, R. A. San Mateo, and S. S. Idos (2001). Guide to student teaching. Quezon City, Philippines: JMC Press, Inc.

iii. Cadosales, M. N. Q. (2004). "The BEED Student Teaching Program of Teacher Education Institutions in Ozamiz City: Proposed Competency Enhancement Training Packages". Unpublished PhD in Education Dissertation, University of San Carlos, Cebu City.

iv. Coladaci, T. (1992). Teachers' sense of efficacy and commitment to teaching. Journal of Experimental Education, 60, 323-337.

v. Creswell, J. W. (2012). Educational Research, Fourth Edition Boston, Pearson.

vi. Fives, H.R., Hamman, D., and Olivarez, A. (2005, April). Does burnout begin with student teaching? Analyzing efficacy, burnout, and support during the student-teaching semester. Paper presented at the Annual Meeting of the America Educational Research Association, Montreal, CA. vii. Frank, T. H. (2005). The handbook for developing supportive learning environments. New York: Eye on Education.

viii. Gordon, S. P. (2005). Standards for instructional supervision. New York: Eye on Education.

ix. Hoy, A. W. and W. K. Hoy (2009). Instructional leadership: a research-based guide to learning in schools. Boston: Pearson.

x. Pajares, F. (2000, April). Seeking a culturally attentive educational psychology. Paper presented at the annual meeting of the American

Educational Research Association, New Orleans. Retrieved: May 23, 2005, from http://www.emory.edu/EDUCATION/mfp/AERA20 00Discussant.html

xi. Podsen, I. J. and V. M. Denmark (2000). Coaching and mentoring first-year and student teachers.ebook: http://www.amazon.com/Coaching-MentoringFirst-Student-Teachers/dp/1883001803

xii. Quinco, Maria Nancy Talamo (2000, March). Correlates of college students' academic performance. Unpublished Master's, Immaculate Conception College-La Salle, Ozamiz City.

xiii. Tabasa, M. L., Tampus, G. P. and Gonzales, J. C. P (2002). Student teaching handbook: a project of PROBE and CHED Region VII.

xiv. Teacher Education Council, Department of Education, Commission on Higher Education (2009). Experiential learning courses handbook.

xv. Tucker, P. D., J. H. Stronge, C. R. Gareis (2002). Handbook on teacher portfolios for evaluation and professional development. New York: Eye on Education. 